\title{
Biographical Fiction to Historiographic Metafiction: Rewriting Clara Schumann
}

\begin{abstract}
Clara Wieck Schumann was one of the leading concert pianists of the nineteenth century. Her story has been captured in several "fictionalised biographies," texts which transgress genre boundaries and renegotiate the relationship between historical fact and fiction. This essay will compare Janice Galloway's novel Clara (2002) with J. D. Landis's Longing (2000), Werner Quednau's Clara Schumann (1955), and Dieter Kühn's play Familientreffen (1988) in order to point out some of the choices the liminal status of biofiction affords the author and the effect of these choices on the portrayal of the heroine. Analyses will draw on Wolfgang Iser's reflections on the fictionalising act and Linda Hutcheon's notion of historiographic metafiction, demonstrating that writers' interest in Clara Schumann has resulted not only in widely differing portrayals of the pianist's life but also in manifestly different classes of texts.
\end{abstract}

Key words

Clara Schumann; biographical metafiction; historical fiction; historical novel; bioplay

Clara Wieck Schumann was one of the leading concert pianists of the nineteenth century. Born in Leipzig in 1819, she received her musical training from her father, Friedrich Wieck, and fell in love with Robert Schumann at the age of sixteen. Wieck battled fiercely with Schumann over the control of his daughter's fortunes, but lost her to the young composer, whom she eventually married in 1840. After attempting suicide in 1854, Robert Schumann was committed to an asylum where he died only two years later. Clara Schumann continued her successful musical career until her death in 1896.

Clara Schumann's story has been captured in several biographies, as well as in biographical films, plays, and novels - i.e. "fictionalised biographies." The 
fictionalised biography is an interesting hybrid genre, placed somewhat uncomfortably between historiography and the art of fiction. The notion of historiography and fiction as absolute opposites has long been called into question from both sides of this apparent divide: on the one hand, works of fiction may contain a wealth of meticulously researched historical "facts." On the other hand, the view that a "factual" biography is "precisely referential of the person" the text aims to "reconstruct" has been derided as a "realist fallacy" (Stanley 1992: 8). It is nevertheless useful to conceive of factual and fictionalised biographies as two different modes of life-writing that follow different conventions. Fictionalised biographies are permitted to disregard certain expectations raised by factual ones for instance that authors should strive for "objectivity" or "truthfulness" - which allows them to renegotiate the relationship between fact and fiction. This artistic freedom may well be the reason for the striking differences which can be found among fictionalised versions of Clara Schumann's life.

This essay will compare Janice Galloway's novel Clara (2002) with other fictionalised treatments of Schumann - notably, J. D. Landis's Longing (2000), Werner Quednau's Clara Schumann (1955), and Dieter Kühn's play Familientreffen (1988) - in order to point out certain choices the "fictionalising act" affords the author and to highlight the effect of these choices on the portrayal of the heroine. Analyses of these texts will draw on Wolfgang Iser's conception of the fictionalising act as based on a triad of the real, the fictive, and the imaginary, as shall be briefly explained in the following.

\section{The Fictionalising Act}

In The Fictive and the Imaginary, Wolfgang Iser states that "a piece of fiction devoid of any connection with known reality would be incomprehensible" (1993: 1). Taking this contention as the starting point of his argument, Iser goes on to discard the traditional distinction between reality and fiction, replacing it with a triadic relationship of the real, the fictive, and the imaginary. A text's "fictional features do not constitute an end or an entity unto themselves" (1993: 2), Iser claims, but rather should be conceived of as a "fictionalising act," which can be divided into three functionally distinct acts: "selection," "combination," and "self-disclosure."

Selection as a fictionalising act "encapsulates extratextual realities into the text, turns the elements chosen into contexts for each other, and sets them up for observation against those elements it has excluded" (1993: 6). These extratextual elements - extratextual here in the sense of "from outside the fictional text in question" - are selected "from a variety of social, historical, cultural, and literary systems that exist as referential fields outside the text" (1993: 4). Combination is the fictionalising act that organises the selected elements into patterns and thus sets them in relation to each other (1993: 7-11). Ansgar Nünning, whose work on historical fiction draws on Iser's theory, has renamed this act "configuration," 
which he defines as "the collective literary techniques of narration and structuring" (1995: 63, my translation). ${ }^{1}$ This concept of configuration is reminiscent of that of "emplotment," as proposed by Hayden White in a historiographic context, which denotes the operation of "making stories out of mere chronicles," i.e. "the encodation of facts contained in the chronicle as components of specific kinds of plot structures" (2001: 223). Self-disclosure, finally, refers to "the fictional text's disclosure of its own fictionality" (Iser 1993: 11).

Unlike the historian, the novelist integrates elements from the realm of "the imaginary" into his/her work and endows it with signals of "self-disclosure." However, just like the "factual" biography, fictionalised biography is shaped around the selection and configuration of "extratextual realities," i.e. of available facts about the biographical subject. The following analyses are structured around the fictionalising acts of selection and configuration so as to shed light on the different ways in which Clara Schumann has been "re-written" in fiction.

\section{Selection: Choosing from the Records of a Life}

Clara Wieck was twelve when she played for Johann Wolfgang von Goethe in his residence in Weimar. What Friedrich Wieck wrote in his diary in October 1831 translates as follows:

On 1 October at 12 o'clock noon we had an audience with His Excellency, the 83-year-old Minister Goethe. We found him reading, and the servant led us to him without further announcement, since he had invited us for this time on the previous day. He received us warmly; Clara had to sit down next to him on the sofa. Soon, his daughter-in-law arrived with her two cleverlooking children of 10 to 12 years. Clara was now asked to play, and as the stool in front of the piano was too low, Goethe himself fetched her a cushion from the hall and arranged it for her. She played "La Violetta" by Herz.

(qtd. in Litzmann 1902: 28-29, my translation) ${ }^{2}$

In Janice Galloway's novel Clara, this visit is referred to in a passage in which the twelve-year-old Clara reflects on her concert tour as she is asked by her family to impart her experiences:

she had given a great many [concerts]; in halls little more than barns with not enough light to see by, others in palaces, with royal families in matching sets waiting round a piano so patterned with inlays and painted landscapes it seemed an affront to touch it at all.

She had played for Goethe with all his hair after eighty-one years, who fetched her cushions and sweets; for Spohr who held her hands and told her they were treasures from God; for Mendelssohn and Chopin who looked like princes till she saw them bear-fighting, giggling like boys in a salon 
ante-room. Yet, how beautiful - she could think of no other word for it Herr Chopin looked when he listened! (Galloway 2002: 92-93)

The audience with Goethe also features in Werner Quednau's Clara Schumann, where it is rendered in a mixture of direct speech and reported action:

"My young lady, I have been told that you are an accomplished artist. If such a charming child as you would like to play something for me too [...] it would be a pleasure for an old man like me. The young go their own ways, also in art. Whether it is always the right one, I do not want to decide. The future must teach us that. But a handsome child that labours for art is always a refreshing experience."

These simple, warm words of the old poet took away Clara's shyness. She curtsied and sat down at the grand piano. But the stool was a little too low, so that she had to lift herself up on her toes. Goethe, who noticed this, stood up, fetched her a cushion, and arranged it for her.

(Quednau 1961: 57, my translation) $)^{3}$

For Quednau, the audience with Goethe is apparently of much greater significance. He devotes a whole scene to it, in which the narrator relates, in his usual patronising tone, how the cute little girl Clara is allowed to play for the worldfamous poet, emphasising, as Wieck does in his diary entry, that Goethe even did her the honour of personally fetching a cushion. Galloway, by contrast, does not place much emphasis on the fact that Clara had the "honour" of meeting an immensely famous poet, but rather presents the incident from the perspective of a young girl who probably did not have the same idea of Goethe's "greatness" as her father, or readers today.

It is worth noting that the title of Quednau's novel, Clara Schumann, suggests a focus on Clara's role as Robert Schumann's wife and the great "romance" of their relationship. Had the title been Clara Wieck Schumann, it would also have drawn attention to Clara's life before she got married: to a young girl called "Clara Wieck," who was already famous under her father's name as an outstanding pianist and who later chose to take on a different name by marriage. Galloway, then, chose a title that is free of such markers of "belonging." "Clara" does not link the heroine to a particular man but allows her to stand for herself, which anticipates the novel's fundamental position towards the rewriting of Clara's life.

As in Quednau's Clara Schumann, the encounter with Goethe features prominently in J. D. Landis's Longing:

Goethe invited Clara to perform for him, and for his grandchildren, and, as Clara wrote to Robert:

He went out of his way to rise from his chair - he is over eighty and none too swift of foot nor straight of spine - to find a pillow for me. He delivered it to me at the piano and pushed it under my fanny in such a way that 
his hand, which I could feel and later see had a ring on nearly every finger, was between the pillow and my fanny itself. And wouldn't you know that hand stayed right there, as if to arrange the pillow though it was my fanny he nearly rearranged and almost caused to close together upon his hand and trap it there. When indeed the piano bench was of sufficient height for me without either a pillow or his naughty hand. And yet once he withdrew his hand, I think his grandchildren heard me better than did he.

(Landis 2000: 92)

Landis casts the Goethe visit in the form of a letter that Clara supposedly wrote to Robert, in which she tells Robert about her "fanny" being improperly touched by the poet's "naughty" hand. These lurid physical details appear throughout the novel, as though their purpose were to make the book more interesting, sensational, and entertaining for twenty-first-century readers. Another example of this kind is the novel's inclusion of a premarital sexual encounter between Clara and Robert, for which no source exists ("'You desire me?' / 'Yes.' / 'With all your heart?' / 'Yes.' / 'And with all the rest of you as well?'” Landis 2000: 220). Thus, although the source for Clara's Goethe visit must have been the same for all three novels, i.e. Friedrich Wieck's diary entry, their fictionalised accounts differ greatly in the way they make use of it.

Landis's Clara, in her letter to Schumann, goes on to tell of Goethe's love of young girls, finally relating the old poet's gesture to paedophilia:

I shall put into these secret parentheses some gossip I heard: when Herr Goethe was in his seventies, he fell in love with a teenaged girl scarcely older than I, [...] and it was for her he wrote his Trilogy of Passion poems [...]. Can you imagine! A man like that in love with a mere girl.* I'll bet you can. This story at least went a long way toward explaining to me why he had put his hand upon my fanny. (Landis 2000: 93)

At this point Landis inserts a footnote in which the narrator notes,

*It would be interesting, if impossible, to learn whether Clara is referring to Ulrike von Levetzow or to Marianne von Willemer. The former was fifty-six years Goethe's junior, a difference in age that was of no concern to Goethe himself. (Landis 2000: 93)

Thus, Landis also selects historical facts about Clara's contemporaries that have little to do with the main narrative, and which only serve, it seems, as pieces of "historical gossip." He takes considerable liberties with his "sources," some of which are, in fact, invented and then endowed with an air of authenticity. Nevertheless, this last comment - and its position in a footnote - acknowledges that Longing is based on a selection of historical sources and pre-texts in the first place, drawing attention to the fact that the information these sources provide is 
incomplete. The text here fleetingly points to its own inability to "reconstruct" a life in its entirety from the available source material. Quednau's Clara Schumann, by contrast, contains no such departures from its realist narrative flow: it is an altogether more traditional work aiming to create the illusion of a coherent fictional world.

In their typology of parameters of intertextuality, Ulrich Broich and Manfred Pfister propose the term "auto-reflexivity" ("Autoreflexivität") for a text's reflection on its relation to other texts (1985: 28). Galloway's Clara is marked by a significantly higher degree of auto-reflexivity, which is, however, directed towards a different purpose than in Longing. When Clara reflects on her memories of the recent concert tour, the encounter with Goethe is just one of many other impressions mentioned:

she had played [...] for officials and generals and countless teacup-rattling philistines, supporters and sniffers, for boors, bores and the merely curious. She had seldom been asked for an opinion. She had been given jewellery, medals, accolades, keepsakes, locks of hair from lovesick girls [...] and money. Most of the jewellery was money now, too. But this was nothing to say. It wasn't a story. She had travelled with her father, she had played the piano - that was the long and short of it. She said so - and they laughed.

(Galloway 2002: 93)

This passage highlights that many of the experiences and memories of the biographical subject are evidently not accessible through historical source texts. If something is not considered a "story" it is most likely not worth mentioning, far less so recording. Moreover, in Clara's case the decision of what is worth recording clearly lies with someone else. When Galloway's Wieck finally tells his acquaintances all about their tour - "as he knew he would all along" - the narrator notes that Clara

had recognised his story as she always recognised his stories. He had told what he saw. But she had seen other things, things around the edges of his vision; mere detail of course, nothing so important as what his own eye had lit upon. (Galloway 2002: 95)

Unlike Landis's novel, which suggests that selection from historical records is limited by their gaps, Galloway's Clara questions the validity even of those facts that have been recorded. This critical stance is still more noticeable when Clara's diary is introduced:

My diary begun by my father, the $7^{\text {th }}$ June 1827 and continued by Clara Josephine Wieck. [...] My diary. His own hand. Mine.

The rules emerge and stick. His daughter is $I$, he is father; he sees and knows everything. [...] [H]e imagines he has a talent for the descriptive. This 
is how I walked on stage, why I chose this dress, as though he would know. [...] After a while he can't stop. Father deserves my greatest devotion and gratitude for his ceaseless efforts on my behalf, he writes - no sense of irony at all. (Galloway 2002: 61)

Thus, Clara's diary constitutes one of the rare and complex cases of life-writing in which the author is not identical with the narrating "I", due to the incapacitation, so to speak, of the subject represented by the first-person pronoun. Galloway's selection of elements from the "real" world and the novel's critical comments on the complexity of its own intertextuality lead to the creation of an interesting meta-textual and meta-historical level in Clara, which a more traditional work of historical fiction, such as Quednau's Clara Schumann, lacks more or less completely. Clara can thus be classified as historiographic metafiction, in Linda Hutcheon's sense of a self-reflexive text that "offers a sense of the presence of the past, but this is a past that can only be known from its texts, its traces - be they literary or historical" (1989: 4).

While authors of biographies may take a critical stance towards the amount of available historical sources and their value as reflections of particular versions of the "truth" in their texts, they certainly all have their own political agendas and versions of "truth," which guide their selection of historical data. For example, Janice Galloway's approach to the life of her heroine is identified by Hermione Lee as a story of "female survival" (2002: 19). Indeed, it seems that Galloway has remodelled Schumann's song cycle Frauenliebe und Leben ("woman's love and life") to turn it into Frauenliebe und Überleben in her book. In its eight chapters, which are named after the songs of Frauenliebe und Leben, the novel focuses on the every-day struggles of a woman who desperately tries to cling to her artistic career, while striving to be a good daughter, wife, and mother. That Clara sometimes fails, especially as a mother, is only hinted at in the novel; it is not given much weight. For example, several years into her marriage, Clara finally convinces Robert to accompany her on a concert tour to Russia, but she has to leave her children behind:

Pauline and Carl arrived for the children, Marie screaming, her little face purple with misery and rage as soon as she saw them, already aware what the appearance of these relatives meant. Unbearable, her resistance; Clara lifting her daughter while the child kicked and struggled, held the sides of the chaise door; maddening to the point of tears that she would not stop. Robert watched all from the window, his expression unaltered, unfaltering, as though it were a play. [...] But this was the cost of Art, there was no help for it. (Galloway 2002: 262) ${ }^{4}$

Although Robert is once more set up as the "bad parent," who seems completely unmoved while Clara is much agitated by the violent separation from their daughter, one cannot but notice that he is not entirely to blame. Throughout the 
novel the children play a minor role for Galloway's Clara: that of an obstacle, a further burden that Clara has to bear on her rocky path to personal liberty and stardom. After the birth of her first daughter Marie, we are given a glimpse of the mature Clara's thoughts:

Who understands, looking at a first child, what is to come? How little say one has in any of it? Wayward Elise. Sickly Julie. Emil, God rest his soul. Troublesome, troubled Ludwig. Ferdinand, shy and clinging to a fault. Fretful, wistful Eugenie. (Galloway 2002: 215)

Judging by Galloway's selection and contextualisation of the "facts," Clara is to be pitied for the incredible responsibility that has been forced upon her by the sexual greed of her misogynist husband, who has cunningly removed her further from her personal ambitions through a number of unwanted pregnancies. When she is expecting her third child, he "knew she was pregnant again almost as soon as she did. He had been keeping a note of her menstrual dates, planning his sex life with meticulous care" (Galloway 2002: 272). In this version, Clara is unquestionably a "victim."

Dieter Kühn has produced a play about Clara Schumann that presents us with a different picture. Its title Familientreffen can be translated as "family reunion." In contrast to Galloway's novel, which ends on Robert Schumann's death and thus omits Clara Schumann's 40-year widowhood, Kühn's play revolves around a meeting between an elderly Clara and her grown-up children. Ludwig suffers from manic depression and has been living in a mental asylum for a decade, while Ferdinand has succumbed to drug addiction. None of the children has had a happy life, and in the course of the meeting they blame Clara for her failures as a mother. Eugenie complains that she was never there for them, that she separated them and left them with relatives or sent them off to boarding schools simply to be rid of them and enjoy her exciting career as a concert pianist. Ferdinand demands money to pay for his morphine: "Mama, you ought to transfer some of the radiance of the impending festivities onto your son and contribute to his inner illumination" (Kühn 1988: 21). He ironically adds: "In this opiatically illuminated condition everything is as beautiful as you would surely like to read in a biography" (1988: 22, my translation ${ }^{5}$ ). Thus, a meta-biographical level is opened up when Ferdinand reflects on the quasi-fictional character of future biographies of his mother, pointing out how the selection of certain "facts" and the exclusion of others will create an idealised version of Clara's life. At the same time, as the only fictionalised work to incorporate the hardships of Clara's children - attributing them to her failure as a mother-Familientreffen is itself an excellent example of the crucial role that selection, as a fictionalising act, plays in the characterisation of the biographical subject. 


\section{Configuration: Arranging the Records of a Life}

Fictionalised biographies are characterised not only by the paradigmatic selection of extra-textual elements but also by the syntagmatic relations between these elements, as established by the fictionalising act of configuration. As mentioned previously, Nünning defines configuration as "the collective literary techniques of narration and structuring" (1995: 63). In order to demonstrate how configuration determines the presentation of history and character in fictionalised biographies of Clara Schumann, narrative perspective and speech representation shall be briefly examined in the following analysis.

In Janice Galloway's Clara, focalisation is mostly internal to the story, Clara being the novel's main character focaliser (Rimmon-Kenan 2002: 74): most of the action and other characters are rendered through her perspective. The impact of the novel's chosen centre of consciousness can best be observed by comparing the following passages on the 1849 "May Uprising" in Dresden, the first of which is taken from Clara:

\section{Barricades.}

The city had been molehilled overnight; paving stones and sewer lids, planks and wooden boxes, poles from carriages and cart axles, a wardrobe with a carved wooden face. There was more of the same all the way to the market, handcarts piled with debris and men shouting [...] The King had made a run for it and left his cast-offs in charge at the town hall. The Neustadt was full of soldiers with six sets of orders; thousands of them, Prussian bastards, hand-picked. The roads round the castle weren't safe. She caught the word cannon here and there. (Galloway 2002: 314)

The same uprising is described in Landis's Longing as follows:

Because their weapons were proving useless against the superior power of the combined Saxon and Prussian armies, the rebels had erected barricades in the streets, quite in the French tradition and thus a triumph of delusion over design. Indeed, their design was said to be the work of Richard Wagner, who had been preaching for several years that the new Germany was like a bronze statue awaiting a single hammer blow in order to be freed from its mold, as well as from the fungus of Jewification. These ramparts were a collaboration of paving stones, rubble stones, wooden beams, iron rods, ... and such humans as were foolish enough to think such a pile of rubbish might have the force of the commandment Thou Shalt Not Shoot Me. (Landis 2000: 345)

Both passages relate to Clara Wieck Schumann's diary entry from 4 May, in which she describes the barricades and mentions, for example, the paving stones that were used to build them (see Litzmann 1902: 186), but Longing draws on 
other historical sources as well; Wagner's contribution to the May Uprising, for instance, is not mentioned at all in Clara's diary.

Landis's focaliser is a narrator-focaliser, external to the story. Longing is thus narrated from a "bird's-eye view," as Rimmon-Kenan explains (2002: 75-78), meaning that the focaliser has unrestricted knowledge about characters and events. When "the superior power of the combined Saxon and Prussian armies" or the "rebels" are mentioned in Longing, for example, it is in a way that is not emotionally coloured. In Galloway's novel, by contrast, we encounter the Prussian army as "Prussian bastards," exactly because the focaliser is Clara, who happens to sympathise with the rebels. If Longing ridicules the Dresden rebels, it is not because the novel takes sides against them but, more probably, because history has proven the rebels to be weaker. From a twenty-first century perspective, their endeavours may appear futile and even ridiculous.

The external focalisation in Longing also becomes noticeable through Landis's tedious habit of incorporating as many historical facts or anecdotes as possible. While Richard Wagner may have had his share in the revolution, his anti-Semitism and his political role were surely not the first things the Schumanns would have reflected on when they saw the barricades or heard the gunfire. When the barricades are described in Clara we are told that there was "more of the same all the way to the market" because Clara is walking down the way to the market and it is what she sees. There is no room for humour in Galloway's depiction of the events, since they would not have seemed amusing to Clara, but rather alarming and frightening. In an interview for the Austrian magazine Buchkultur, Galloway notes that she consciously chose to write from Clara's perspective: "I wanted to tell it as HER story. And I did. This is not 'taking sides' but choosing a perspective to write through" (Galloway 2003). This may be the reason why Elizabeth Hawksley complains of the "emotional claustrophobia" of Galloway's novel, observing that "the outer world seems scarcely to impinge" (2002: 19).

Not only is our view of events in Galloway's novel restricted by Clara's perspective, but our view of Clara herself is also limited by the novel's mode of speech representation:

Next time, she thought, scouring, when Papa said, Tell Dr Carus how Paganini plays, Clärchen; what Goethe said; what that rather stuck-up fellow Heine looks like; what refinement Mendelssohn, the son of a Jewish banker, can display, she would say something dazzling. The reflection of her face appeared in the blades as she worked, her lips parted as though ready to speak. (Galloway 2002: 96-97)

When Clara returns from her concert tour, she has nothing to say, or is not afforded an opportunity to speak. However, the expectation that Clara's voice will be "audible" later in the novel, that she will be heard to "say something dazzling" is not fulfilled. We learn about her tour to Paris that 
without prompting she allowed herself to sicken of concerts, at least as far as listening was concerned, if she pleased. Away from her father, Clara found plenty to say and most of it she said to other women.

(Galloway 2002: 167-168).

The point is, however, that we never actually hear what she has to say. In fact, Galloway's heroine can hardly be "heard" to say anything at all, as most of the time her speech is reported: "What did she do? She wrung her hands, talked of love to the Old Man, begged to be understood" (Galloway 2002: 138). The same is true of her thoughts, as in the following example when Wieck plays on her feelings of guilt over her affection for Schumann:

Clara. I have taught you everything, given you everything. Do not forget. [...] You will never be able to repay me for all I have done for you.

Looking into his eyes, her face betraying nothing, Clara felt the most terrible pity, lurching in her stomach, washing in waves. Her head, meantime, checked some arithmetic - 2000 a year, not Leipzig. Turning itself towards the future, elsewhere, away. (Galloway 2002: 158)

When she does speak, we are often told of all the things she does not say at that moment, as in the following scene, when young Joachim asks her, on hearing her trio, what it is like to compose:

Writing music is a matter of patience, she said. Patience and persistence and reading. I have studied a great deal. Herr Doctor Mendelssohn will tell you how important it is to - But inspiration, he persisted. [...] Felix's eyes lit upon her, the corners of his mouth twitched. And all she had in her mouth were plain things, and he knew it. Practicalities. Apologies. You might ask my husband next time we meet, she said. He always knows what to say.

(Galloway 2002: 306)

This passage is preceded by a page-long description of what composing is actually like for Clara, which, however, is never uttered by her. While Clara's voice can rarely be heard "directly," Wieck, Schumann, or Mendelssohn are often allowed to express themselves in longer stretches of direct discourse in Clara, which, according to Rimmon-Kenan, "creates the illusion of 'pure' mimesis" (2002: 111).

The effect of the silence that characterises Clara in Galloway's novel can best be observed by comparing Clara to Landis's Longing. In the following passage, Galloway's Robert Schumann tells his wife that he does not wish to accompany her any further on her concert tour to Copenhagen ${ }^{6}$ :

A woman might not travel alone. Did he mean her - she could hardly say it - to cancel? Not to fulfil her concert dates and deliberately take back her word? To pay compensation costs, travel costs, hire costs and hotel deposits 
out of only what they had so far earned? [...] Of course he didn't mean her to cancel. That was an unfortunate by-product of his perfectly justifiable disinclination to continue. [...] Eventually, he lost patience with waiting for her to give in and said what he should not. Go on if you must. Get a pupil or a chaperone or some other hired stranger and go to Copenhagen. Why not? Never anticipating, not really, that there and then she would burst into tears and simply accept. (Galloway 2002: 232-233)

The argument is filtered through Clara's consciousness. Towards the end of the passage Robert's words are presented in direct discourse, while Clara's are rendered once more in free indirect discourse. The same incident can be found in Landis's Longing, where the couple's speech is presented differently:

He waited for her in their hotel room. He could neither read books nor write music.

"I've become nothing more than your traveling companion," he said when she'd returned. / "Travel into my arms." For the first time, he did not. / "I must return home," he said. / "And I must not," she replied. / "I can't very well ask you to give up your music because I am chained to mine." / "You may ask." / [...] "You must go without me," he said. / "Yes, I must. We need the money." / "You sound like your father." / "We need the money." She was right. (Landis 2002: 308-309)

Both Robert's and Clara's speech is rendered in direct discourse here and therefore "rings out" equally from the page. In Galloway's novel, by contrast, Clara's speech is grafted onto the narrator's. Throughout the novel, other characters' words feature far more prominently and are presented in a more direct way than Clara's own speech. Unsurprisingly, Galloway notes in the previously quoted interview that in writing the novel, "the thing that mattered, was the silent Clara herself" (Galloway 2003, emphasis added). Thus, Clara has effectively been silenced - in line with Clara's perceived role as "victim."

\section{Conclusion}

The comparison above of fictionalised biographies of Clara Wieck Schumann has revealed some of the aesthetic and political choices authors are allowed to make when rewriting a life in fiction. The transformation process involved has been traced through the fictionalising acts of selection and configuration as particular images of the biographical subject are generated by both the author's choice of extra-textual elements and by the setting of these selected elements in relation to each other through devices such as narrative perspective and speech representation. Janice Galloway's novel Clara foregrounds Clara's daily struggles for artistic independence under the double burden of marriage and child care, pic- 
turing her as a victim of patriarchy, while Dieter Kühn's play Familientreffen focuses on her responsibility, and failure, as a mother. Werner Quednau's Clara Schumann presents a highly traditional tale of the exceptional life of a talented "good" woman, which is occasionally commented on by an omniscient narrator with patronising benevolence. Finally, in J. D. Landis's Longing Clara emerges as a buoyant wunderkind that later turns into a promiscuous heart-breaker who constantly indulges in silly word games.

Furthermore, it has been shown that the liminal status of fictionalised biography on the interface of historiography and "the imaginary" invites some authors to transcend the conventions of traditional historical fiction and embrace the tenets of historiographic metafiction in their rewriting of Clara Schumann. Such texts question the knowability of an individual life and of history as a whole, as they reflect upon the partial narratives of life writing and consequently, on their own status as literature. Thus, writers' interest in Clara Schumann has resulted not only in widely differing portrayals of the pianist's life but also in manifestly different classes of texts.

\section{Notes}

1 'Durch die Einführung des Begriffs 'narrative Konfiguration' von Geschichte anstelle von 'Kombination' soll verdeutlicht werden, daß nicht nur die Verknüpfung der Elemente auf der syntagmatischen Achse für narrativ-fiktionale Geschichtsdarstellung relevant ist. Vielmehr soll dieser Begriff die Gesamtheit der literarischen Erzähl- und Strukturierungsverfahren [...] bezeichnen."

2 "Den ersten Oktober mittags 12 Uhr hatten wir Audienz bei dem 83jährigen Minister Excellenz von Goethe. Wir fanden ihn lesend, und der Bediente führte uns ein ohne weitere Anmeldung, nachdem er uns den Tag vorher zu dieser Zeit hatte bestellen lassen. Er empfing uns sehr freundlich; Clara mußte sich zu ihm auf das Sopha setzen. Bald darauf kam seine Schwiegertochter mit ihren beiden sehr geistreich aussehenden Kindern von 10-12 Jahren. Clara wurde nun aufgefordert zu spielen und da der Stuhl vor dem Klavier zu niedrig war, holte Goethe selbst aus dem Vorzimmer ein Kissen und legte es ihr zurecht. Sie spielte 'La Violetta' von Herz."

3 “"Mein kleines Fräulein, man hat mir erzählt, daß Sie eine vollendete Künstlerin sind. Wenn so ein reizendes Kind auch mir etwas vorspielen möchte... es wäre eine Erquickung für mich alten Mann. Die Jugend geht neue Wege, auch in der Kunst. Ob es immer der richtige ist, will ich nicht entscheiden. Das muß die Zukunft lehren. Aber ein schönes Kind, das sich ernsthaft um die Kunst bemüht, ist immer ein erfrischendes Erlebnis.'

Diese schlichten, warmen Worte des greisen Dichters nahmen Clara ihre Schüchternheit. Sie machte einen tiefen Knicks und setzte sich an den Flügel. Doch der Stuhl war etwas zu niedrig, so daß sie sich mit den Zehenspitzen ein wenig anheben mußte. Goethe, der dies bemerkte, stand auf, holte ein Kissen herbei und legte es Clara zurecht." See Nauhaus (1987: 276) for the Schumann's separation from their children in January 1844. "Mamá, du solltest ein wenig vom Glanz der bevorstehenden Festlichkeiten auf deinen Sohn übertragen und zu seiner inneren Aufhellung beitragen. [...] In diesem opiatisch illuminierten Zustand ist alles so schön, wie du es in einer Biographie gewiß gerne lesen würdest" (Kühn 1988: 21-22).

6 See Litzmann (1902: 41-43) and Reich (2001: 89) for Clara's separation from Robert during her journey to Copenhagen. 


\section{References}

Broich, Ulrich, and Manfred Pfister (eds.) (1985) Intertextualität: Formen, Funktionen, anglistische Fallstudien. Tübingen: Niemeyer.

Galloway, Janice (2002) Clara. London: Jonathan Cape.

Galloway, Janice (2003) 'Interview’ by Dörte Eliass. Janice Galloway Web Archive. 21 July 2003. $<$ www.Galloway.1 to1.org $>$.

Hawksley, Elizabeth (2002) 'Clara'. The Historical Novels Review 21. 19.

Hutcheon, Linda (1989) 'Historiographic Metafiction: Parody and the Intertextuality of History'. In: O'Donnell, Patrick, and Robert Con Davis (eds.) Intertextuality and Contemporary American Fiction. Baltimore: Johns Hopkins University Press. 3-32.

Iser, Wolfgang (1993) The Fictive and the Imaginary: Charting Literary Anthropology. Baltimore: Johns Hopkins University Press.

Kühn, Dieter (1988) Familientreffen. SterzDruck 3. Graz: Sterz.

Landis, J. D. (2000) Longing. New York: Ballantine Books.

Lee, Hermione (2002) 'All Reputation'. London Review of Books. 17 October 2002. 19-20.

Litzmann, Berthold (1902) Clara Schumann: Ein Künstlerleben nach Tagebüchern und Briefen. Vol. I: Mädchenjahre. Leipzig: Breitkopf und Härtel.

Nauhaus, Gerd (1987) Robert Schumann Tagebücher. Vol. II. Basel: Stroemfeld/Roter Stern.

Nünning, Ansgar (1995) Von historischer Fiktion zu historiographischer Metafiktion. Vol. I. Trier: WVT.

Quednau, Werner (1961 [1955]) Clara Schumann. Gütersloh: S. Mohn.

Reich, Nancy (2001) Clara Schumann: The Artist and the Woman. $2^{\text {nd }}$ ed. Ithaca: Cornell University Press.

Rimmon-Kenan, Shlomit (2002) Narrative Fiction: Contemporary Poetics. $2^{\text {nd }}$ ed. London: Routledge.

Stanley, Liz (1992) The Auto/Biographical I: The Theory and Practice of Feminist Auto/Biography. Manchester: Manchester University Press.

White, Hayden (2001 [1978]) 'The Historical Text As Literary Artifact'. Reprinted in: Geoffrey Roberts (ed.) The History and Narrative Reader. London: Routledge. 221-236.

Julia Novak is assistant professor of English Literature at the University of Vienna and founder and artistic director of Vienna Lit, a literary society dedicated to the promotion of literature/s in English. She is a published poet and editor of a collection of stories about Vienna, Vienna: Views (2006). She has written a book on reading groups, Gemeinsam Lesen: die Buchgruppe als soziales Phänomen und ökonomische Triebkraft (2007), and a book entitled Live Poetry: An Integrated Approach to Poetry in Performance (2011).

Address: Dr. Julia Novak, Department of English and American Studies, University of Vienna, AAKH Hof 8.3, Spitalgasse 2-4, A-1090 Vienna, Austria. [email: julia.novak@univie.ac.at] 